\title{
FACTORS AFFECTING THE LENGTH OF PROCEDURE IN PUBLIC PROCUREMENT: THE CASE OF THE CZECH REPUBLIC
}

\author{
Michal Plaček, Martin Schmidt, František Ochrana, Milan Půček*
}

\begin{abstract}
The article deals with the issue of the length of procedure in public procurement. Our analysis focuses on construction contracts in 2010-2015. We apply hierarchical linear regressions to these data to identify factors that affect the length of procedure. According to our results, the duration of a public contract does not affect the standard contract price. The nature of the contracting authority, the expected value, the openness of the procurement procedure, and the method of evaluation have a statistically significant impact on the length of the contract. As for other factors regarding the length of awarding time, the use of the subcontractor, the division of a contract into parts, and a review by the Office for the Protection of Competition due extend the time required. By contrast, contracting time can be reduced by the use of outsourcing. In the end of the article, we have put forward recommendations for economic policy and further research.
\end{abstract}

Keywords: public procurement, delays, decentralization, accountability

JEL Classification: H57, H72, H77

\section{Introduction}

The public procurement process highlights the trade-off between avoiding corruption and giving officials the flexibility to make decisions in the light of their own knowledge (RoseAckerman, 1999; Lennerfors, 2007). The procurement process is exposed to volatility and ambiguity (Carson et al., 2006). "Volatility refers to the rate and unpredicted ability of change in an environment over time, which create uncertainty about future conditions. Since it is difficult to anticipate all possible future contingencies ex ante, ex post adjustments usually become necessary in volatile environments" (Carson et al., 2006). "Ambiguity is less about an uncertain future as about uncertainty about present and past experience. Ambiguity consists of several aspects, including: (1) lack of clear information, (2) uncertainty about the importance of environmental variables, (3) uncertainty of cause-effect relationships between variables, and (4) uncertainty about available courses of action and their potential effects" (Carson et al., 2006). This is a situation that creates a hotbed of opportunism and

* $\quad$ Michal Plaček, Center for Social and Economics Strategies, Prague, Czech Republic (390046@mail.muni.cz);

Martin Schmidt, Center for Social and Economics Strategies, Prague, Czech Republic (m.schmidt@email.cz);

František Ochrana, Center for Social and Economics Strategies, Prague, Czech Republic (frantisek.ochrana@fsv.cuni.cz);

Milan Půček, Vysoká škola regionálního rozvoje a Bankovní institut - AMBIS, a.s., Prague,

Czech Republic (milan.pucek@ambis.cz). 
self-interest which manifests itselfin a wide range of specific behaviours, including bargaining, shirking, failing to fulfil obligations, and withholding valuable information (Williamson, 1985).

In the public process, the contracting authority faces the problem of meeting the aforementioned contradictory objectives that is to comply with strict public procurement rules, and at the same time, fulfil its needs as quickly as possible with the smallest transaction costs. Our article deals with the analysis of factors related to the length of procedure in public procurements. As a first step in this analysis, we present a model that examines the relationship between the length of public procurement and standardized pricing. Via this model, we try to refute or to confirm the assumption that longer awarding time influences the standard price. Simply put, that longer procurement time means better conditions for the state.

Then we focus on analysing the factors that relate the length of procedure in public procurements. We define the median time for the awarding of a public procurement by the central authority as a reference period. While setting up this reference framework, we draw on current literature (OECD, 2011; Březovník et al., 2015) where, there is a consensus that authorities should be faster due to the experience and qualifications of the workers. We can also assume that public procurement by central authorities has the burden of being more complex.

Our research responds to current political social discourse, where the complexity of public procurement legislation (Otidea, 2016) and the resulting transaction costs are very often criticized by the contracting authorities. Thus, the length of procedure in public procurements logically increases these transaction costs. Another reason is the discussion regarding the qualification of the workers, especially on the part of smaller contracting authorities, as well as the discussion on the possible centralization of public procurement or the creation of centralized interfaces.

\section{Theoretical Framework}

The problem of the length of procedure in public contracts has not yet been fully dealt with in the literature. A large part of the literature focuses on time delays in the area of PPP projects, which differ from public procurement by their greater complexity (i.e. De Schepper, Haezendonck, and Dooms, 2015; Sanchez Solino and Gago des Santos, 2017; Erdis, 2013; Dosi and Moretto, 2015).

From our point of view, we consider a key article to be Guccio, Pignararo, and Rizzo (2014) in the article "Do Local Governments Do It Better?" which is an analysis of time performance in the execution of public works looking specifically at the stage of implementation regarding public works, where they compare the efficiency of various types of public authorities in terms of the theory of decentralization. They use, as the main explanatory variable, an institutional category of public procurer and, as the control variables, they use the estimated value of the public contract, weighted public works composition index, the expected duration of the contract, the type of the public contract, the use of the subcontractor, the completion of the project by the given firm, the existence 
of a legal dispute, the relationship between the firm and the contracting authority, the source of financing, and social variables. (Baldi, Bottasso, and Conti, 2016) focus on the analysis of the form of the tender, the resulting prices, and time delays. As the research subject, they considered public contracts of selected Italian municipalities. As explanatory variables, they use the complexity of the public contract, the evaluation criterion used, the estimated value of the public contract, the educational and political characteristics of the municipality's management, the location and size of the municipality, any discount achieved, time delays, the level of trust, and the level of corruption. From a policy perspective, the authors cannot make recommendations without considering important contract characteristics.

\section{Test Hypotheses}

First, we need to test the validity of the assumptions for our theory. We then formulate the following hypothesis, which we verify separately from the other hypotheses formulated.

H1: The length of the tender process does not have a statistically significant effect on the standard price.

Based on the literature search in Section 2, we test whether the selected characteristics of public contracts influence the length of procedure in public contracts. Table 1 presents the established hypotheses, including their previous reflections in the literature.

\section{Table 1 | Specified Hypotheses and Reflection of Factors Affecting the Length of Procedure in Public Procurement in Contemporary Literature}

\begin{tabular}{|l|l|}
\hline $\begin{array}{l}\text { H2: The contracting authority has no effect } \\
\text { on the length of procedure in public procurement. }\end{array}$ & $\begin{array}{l}\text { Brezovnik et al., 2015; Plaček et al., 2017; Plaček } \\
\text { et al., 2016; OECD, 2000, 2007; Dametri et al., 2012 }\end{array}$ \\
\hline $\begin{array}{l}\text { H3: The estimated value of a public contract } \\
\text { does not affect the length of procedure in public } \\
\text { procurement. }\end{array}$ & $\begin{array}{l}\text { Stloukalová, Jurčík, 2015; Fazekas, 2016; Pertold } \\
\text { and Palguta, 2017; Coviello, Mariniello, 2014 }\end{array}$ \\
\hline $\begin{array}{l}\text { H4: The openness of the procurement procedure } \\
\text { does not affect the length of procedure in public } \\
\text { procurement. }\end{array}$ & $\begin{array}{l}\text { Pertold and Palguta, 2017; Borowiec, 2017; } \\
\text { Loader, 2010; Moe et al., 2017; Tkachenko et al., }\end{array}$ \\
\hline $\begin{array}{l}\text { H5: The evaluation process method does not affect } \\
\text { the length of procedure in public procurement. }\end{array}$ & $\begin{array}{l}\text { Decarolis and Palumbo, 2015; Schmidt et al., } \\
2016 ; \text { Ahsan, Rahman, 2017; Nikou et al., 2017; } \\
\text { Lundberg, Bergman, 2017 }\end{array}$ \\
\hline
\end{tabular}

Source: Authors

\section{Data and Utilized Methods}

To test the first hypothesis, the classic OLS model of liner regression was used. The results of this model are given in Appendix. Hypotheses 2-5 are tested by hierarchical regression: Step One the characteristics of the tender (size, contracting authority, etc.), Step Two things that contracting authority may change (just the price as a criterion or not, outsourcing etc.). 
Table 2 | The Overview of the Variables Involved in the Models

\begin{tabular}{|c|c|c|c|}
\hline Variable & $\begin{array}{l}\text { Variable type } \\
\text { for } \mathrm{H} 1\end{array}$ & $\begin{array}{l}\text { Variable type } \\
\text { for } \mathrm{H} 2-\mathrm{H} 5\end{array}$ & Values range \\
\hline Length of procedure & Interval variable & Dependent variable & $10-961$ days \\
\hline Above threshold & Indicator variable & Indicator variable & $0 / 1$ \\
\hline In parts & Indicator variable & Indicator variable & $0 / 1$ \\
\hline Evaluated by price & Indicator variable & Indicator variable & $0 / 1$ \\
\hline EU subsidized & Indicator variable & Indicator variable & $0 / 1$ \\
\hline Number of bids & Interval variable & Interval variable & $1-49$ \\
\hline Estimated price (log) & Interval variable & Interval variable & $\begin{array}{r}52,449-13,000 \text { mil. CZK } \\
\text { (in log } 10.9-23.3)\end{array}$ \\
\hline $\begin{array}{l}\text { Contract price divided by } \\
\text { expected price }\end{array}$ & Dependent variable & Interval variable & $0.10-1.98$ \\
\hline Subcontractor & Indicator variable & Indicator variable & $0 / 1$ \\
\hline $\begin{array}{l}\text { Number of business per } \\
1,000 \text { inhabitants }\end{array}$ & Indicator variable & Interval variable & $158.4-434.7$ \\
\hline Local supplier & Indicator variable & Indicator variable & $0 / 1$ \\
\hline $\begin{array}{l}\text { Reviewed by } \\
\text { Competition Office }\end{array}$ & Indicator variable & Indicator variable & $0 / 1$ \\
\hline Outsourced Administration & Indicator variable & Indicator variable & $0 / 1$ \\
\hline $\begin{array}{l}\text { Type of contracting } \\
\text { authority }\end{array}$ & Nominal variable & Nominal variable & 9 types \\
\hline Type of award procedure & Nominal variable & Nominal variable & 5 types \\
\hline
\end{tabular}

Source: Authors

For the analysis of the problem, we used data on public contracts for public works awarded in the Czech Republic in the years 2010-2015, which are available in the Bulletin of public procurement. Data on 8,340 public works contracts or parts awarded (after removing missing entries) were used for this investigation. This is regarding the public contracts that were awarded in the period. Additionally, data was used from the business register as well as other public databases of the Czech Statistical Office and details of administrative proceedings in procurement matters with the Office for the Protection of Competition (Competition Office), which are available in reports of decisions of the Competition Office. The influence of relevant factors was studied using an econometric model (least squares method - OLS). 


\subsection{Variables used}

As a response variable in the model, the length of the award procedure has been used. This value indicates the number of days from the announcement of the award procedure (typically by sending appropriate notification to the Bulletin of Public Procurement) until the conclusion of actual contract for the public contract. The benchmark value for us is the median value of the time when awarded by the central administration, which was 112 days. The average length for an award procedure in the monitored data is 118.3 days. The distribution of this magnitude is shown in the following histogram.

Figure 1 | Histogram of the Length of the Award Procedure

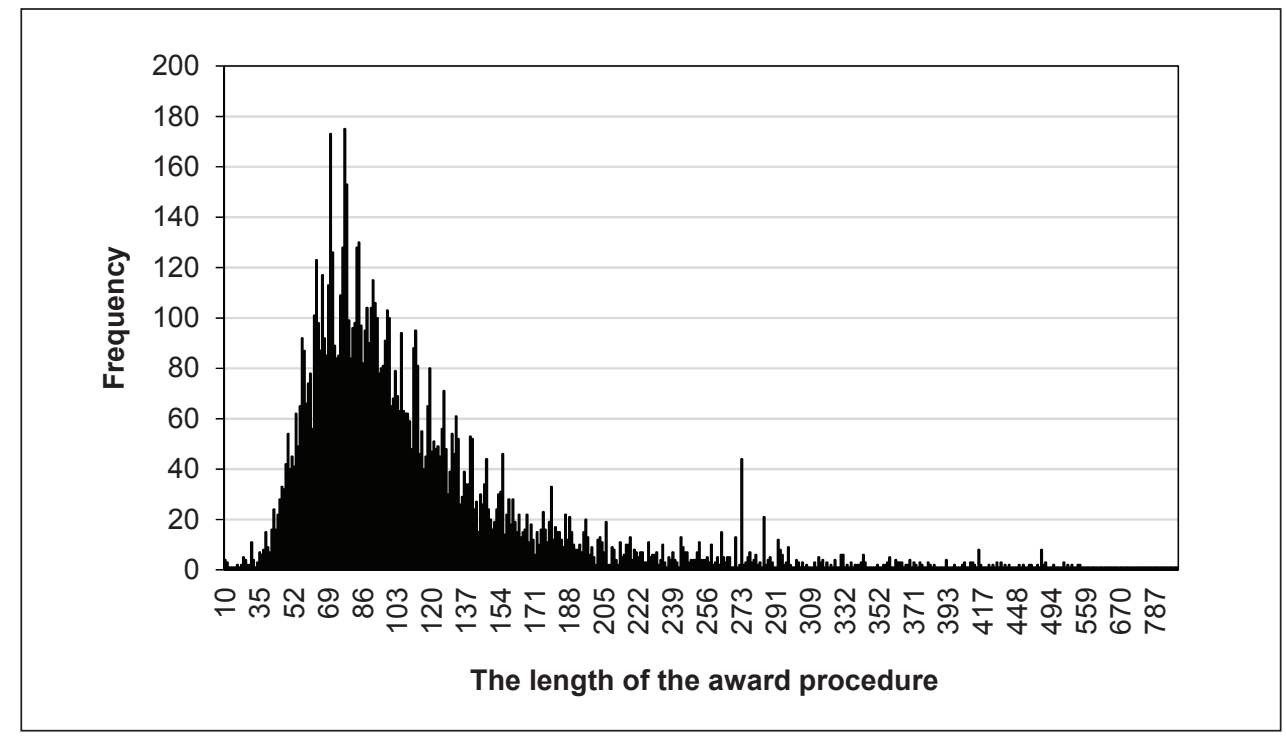

Note: Given that the date of conclusion of the contract is usually manually filled into a form, there may be a (negligible) fraction of errors in the system - such as shorter awarding lengths

Source: Authors

Other factors in the context of an econometric model, are the explanatory variables, which explain (if their influence is statistically significant) the behaviour listed in the res-ponse variable.

First, it deals with the type of contracting authority. The Public Procurement Act distinguishes public subsidized, and sector contracting entities and the Bulletin of public procurement contains different forms for sector contracting entities, but the distribution of public and subsidized contracting authorities is not apparent. In this paper, therefore, the analysed data are from forms designed primarily for public and subsidized authorities. However, there is no assumed division according to the Bulletin, since this separation does not seem very useful and contains significant amounts of incorrectly classified records. Due to the less informative value and improperly divided categories, this data was tracked and categorized in the legal form from the Business Register of the Czech 
Statistical Office (CSO) based on personal identification number (ICO) of the contracting authorities. Based on this, the contracting authorities were categorized into the following groups (see Table 3).

Table 3 | Categorization of the Kinds of Contracting Authorities

\begin{tabular}{|l|c|}
\hline Type of contracting authority & Number of public contracts \\
\hline Department of the state & 793 \\
\hline Region & 1,015 \\
\hline Municipality with fewer than 5,000 inhabitants & 1,306 \\
\hline Municipality above 5,000 inhabitants & 2,723 \\
\hline Funded organization & 1,761 \\
\hline Other public institutions & 483 \\
\hline State enterprise & 495 \\
\hline Nongovernmental organizations & 185 \\
\hline Private business people & 658 \\
\hline
\end{tabular}

Source: Authors

The average length of an award procedure is shown in the following chart.

Figure 2 | The Average Length of the Award Procedure according to the Category of Contracting Authority

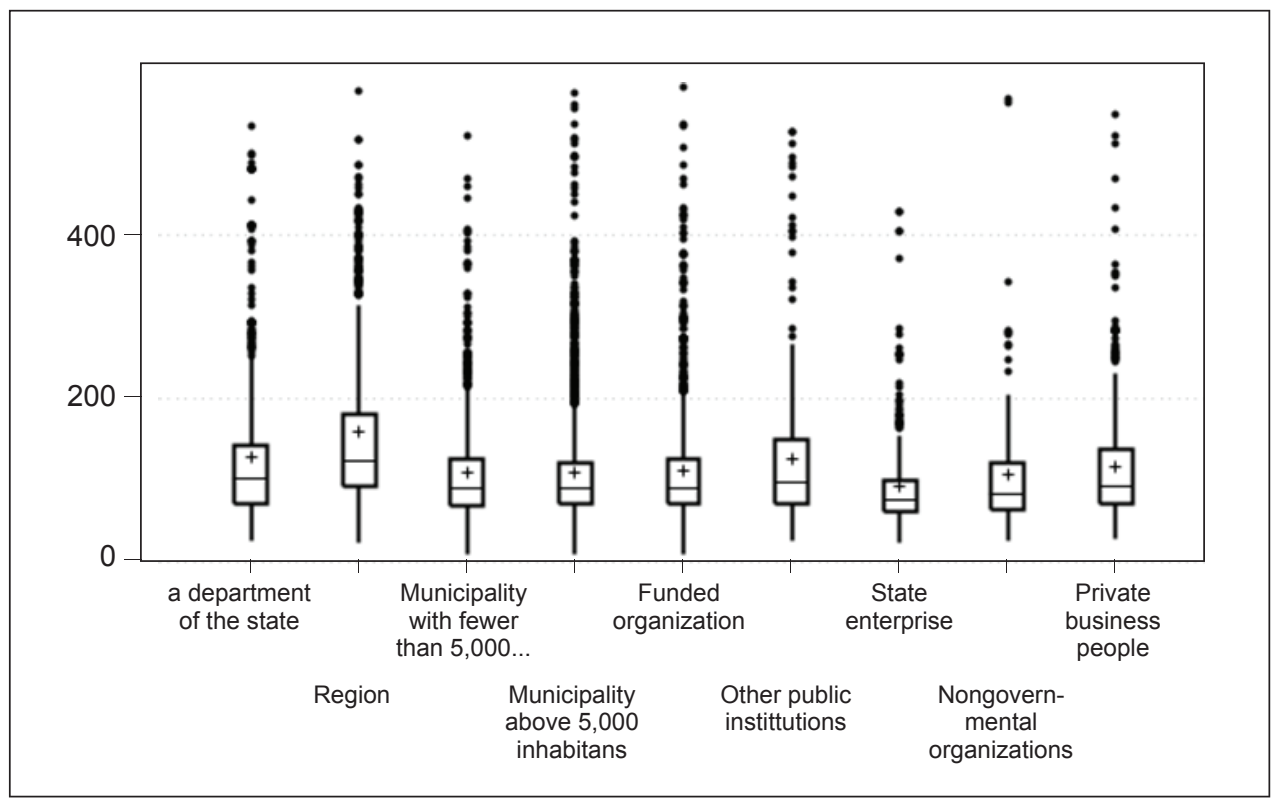

Source: Authors 
Figure 2 shows in boxplots the length of a procurement procedure among different types of contracting authorities. It is obvious that the quicker proceedings take place in the case of municipalities (with slightly different values for large and small municipalities), with slower procedures lay with the central authorities, and the slowest in the case of the regions. These values, however, include the effects of other factors such as the value of the contract, and whether there was an investigation conducted by the Competition Office; the separation of these factors will be carried out further in an econometric model. The average length of a procurement procedure for the selected types of contracting authorities (includes the effects of other variables that will be separated in the context of an econometric model).

Another variable is the type of award procedure, i.e. the specific procedure laid down by law (see Table 4).

Table 4 | Type of Award Procedure

\begin{tabular}{|l|c|}
\hline Type of award procedure & Number of contracts \\
\hline Open procedure & 8,038 \\
\hline Restricted procedure & 1,293 \\
\hline Negotiated procedure without publication & 51 \\
\hline Negotiated procedure with publication & 10 \\
\hline Simplified below-threshold procedure & 27 \\
\hline
\end{tabular}

Source: authors

The Table 4 lists the types of procurement procedure in the framework of the analysed data. It is evident the open and restricted procedures are the most common, but there is not much available data as with other types (e.g. announcing of the tender procedure).

The size of the public contract shows the estimated value of the public contract. This aspect is, along with the administration demands, also included, as well as if it is an above the threshold public contract whose announcement or award is published in the Official Journal of the European Union. Public contracts can also be divided into parts into which individual suppliers can submit bids separately. This factor may complicate a public contract to a certain extent, thereby extending the period of its administration. A higher degree of complication with public contracts may also be related to a public contract being financed by subsidies from the European Union. Due to extra administration, the higher number of bids received may also be increased, all of which the contracting authority must assess.

Another possible explanatory variable, which can be expected to influence the award period, is the evaluation criterion for the selection of the best bid. As already mentioned, the Public Procurement Act allows bids to be evaluated either according to the bid price, or on the basis of several sub-criteria. In this case, this is the evaluation criterion called 
the economically advantageous tender. These two options of bid evaluations will be further presented econometric models captured through the appropriate dummy variables. In the monitored data, approximately $75 \%$ of public procurements were evaluated based on the lowest bid price.

Another possible influence on the explanatory variable could also factors related to the selected suppliers - whether to implement a public contract envisages the use of subcontractors, whether it is a local supplier (located in the same region as the contracting authority), or whether the supplier with whom the contracting authority has certain experience or a relationship (in the model, measured as the number of contracts that a particular supplier has realized within the period for the contracting authorities). The model is also used as an explanatory variable indicator indicating a certain level of development of the region(sponsor's seat)-the number ofbusinesses per 1,000 inhabitants in the district.Additionally, contact details are used to determine whether a public contract is managed by an external company (typically an advisory firm or a law firm).Finally, the length of the procurement procedure may also affect whether or the procurement is subject to review via administrative proceedings before the Office for Protection of Economic Competition (in order to simplify the model, administrative proceedings are not differentiated according to their initiation, or according to the result).

\section{Results and Discussion}

In Appendix, we present the results of hypothesis 1 testing. The model showed that the length of the tender did not have a statistically significant effect on the standard price (the awarded price divided by the expected value of the public contract). We therefore reject hypothesis H1. A statistically significant role is played, however, by the type of contracting authority, the openness of the award procedure, contract size, divisions into parts etc., which, thus, are in line with previous research (Ochrana and Pavel, 2013).

We can therefore move on to test other hypotheses. Table 5 presents the results of our econometric model. In the hierarchical regression, first is the estimated model for characteristics of the contract and in the second model, parameters of the procedure (which the contracting authority can influence) are added.

The coefficient of determination reaches a value of 0.36 , which means that the model describes the behaviour of $36 \%$ of the variance of the response variable. The estimated value of the model can be considered sufficiently strong. The model was also able to satisfy the prerequisites for its adequate usage. Due to the presence of heteroscedasticity residues, robust estimates of standard errors (variant $\mathrm{HC} 1$ ) were used. Among the explanatory variables, with regard to the values of "variance inflation factors" (max 3.6), there was no serious collinearity. In the case of residues of normality, although the conducted tests rejected the hypothesis of normality, however, this requirement may be regarded as fulfilled after the logarithmic transformation (with respect to the number of sightings and residue distribution histogram) (see Wooldridge, 2009, pp. 172-176). 
Table 5 | Results of OLS Regression, the Dependent Variable Length of Award Procedure, Using 8,340 Observations, Heteroscedasticity-Robust Standard Errors (variant HC1)

\begin{tabular}{|c|c|c|}
\hline \multirow{2}{*}{ Variable } & Model 1 & Model 2 \\
\hline & Coefficient & Coefficient \\
\hline Constant & $-199.837^{* * *}$ & $-183.000^{* * *}$ \\
\hline Above threshold & $37.110^{* * *}$ & $32.787^{* * *}$ \\
\hline EU subsidies & $9.471^{* * *}$ & $5.944^{* * *}$ \\
\hline Estimated price (log) & $17.542^{* * *}$ & $14.695^{* * *}$ \\
\hline Number of business per 1,000 inhabitants & $0.096^{* * *}$ & $0.118^{* * *}$ \\
\hline \multicolumn{3}{|l|}{ Type of Contracting Authority } \\
\hline Region & $21.271^{* * *}$ & $18.786^{* * *}$ \\
\hline Municipality $<5,000$ inhab. & $-17.515^{* * *}$ & $-18.606^{* * *}$ \\
\hline Municipality $>5,000$ & $-16.217^{* * *}$ & $-14.147^{* * *}$ \\
\hline Subsidized organization & $-24.295^{* * *}$ & $-24.972^{* * *}$ \\
\hline Other public institutions & $-28.632^{* * *}$ & $-26.637^{* * *}$ \\
\hline State enterprise & $-23.742^{* * *}$ & $-20.873^{* * *}$ \\
\hline NGO & $-31.915^{* * *}$ & $-23.010^{* * *}$ \\
\hline Private business & $-25.605^{* * *}$ & $-17.857^{* * *}$ \\
\hline In parts & - & $32.787^{* * *}$ \\
\hline Evaluated by price & - & $-8.034^{* * *}$ \\
\hline Number of bids & - & $1.943^{* * *}$ \\
\hline Subcontractor & - & $2.877^{* *}$ \\
\hline Local supplier & - & $-3.207^{* *}$ \\
\hline Competition Office & - & $93.758^{* * *}$ \\
\hline Outsourced administration & - & $6.028^{* * *}$ \\
\hline \multicolumn{3}{|l|}{ Type of procedure } \\
\hline Restricted procedure & - & $51.266^{* * *}$ \\
\hline Negotiated procedure without publication & - & $326.528^{* * *}$ \\
\hline R-squared & 0.17583 & 0.36472 \\
\hline Adjusted R-squared & 0.17473 & 0.36311 \\
\hline $\mathbf{F}$ & 76.93268 & 82.93576 \\
\hline P-value(F) & $1.6 \mathrm{e}-180$ & 0.00000 \\
\hline Akaike criterion & $102,926.50$ & $92,654.20$ \\
\hline
\end{tabular}

Note: robust standard errors are used, ${ }^{* * *}$ indicates statistical significance at $1 \%$ confidence level, ${ }^{* *}$ at $5 \%$ confidence level

Source: authors 
When testing hypotheses, we draw from Model 2. Table 6 shows the results of hypothesis testing.

Table 6 | The results of testing the hypotheses

\begin{tabular}{|l|c|}
\hline Hypothesis number & Result \\
\hline H2 & Rejected \\
\hline H3 & Rejected \\
\hline H4 & Rejected \\
\hline H5 & Rejected \\
\hline
\end{tabular}

Source: Author

If we look at $\mathrm{H} 2$ regarding the type of contracting authority per its degree of decentralization, the regions achieve, on average, an 18.8 day longer tender procedure. Larger municipalities (with 5,000 or more inhabitants) achieved a 14.1 day shorter length, and small municipalities managed a 18.6 day shorter length for the award procedure. If we must answer the questions asked by the study by Guccio et al. (2014) that "do local governments do it better?", then the results of the investigation show that decentralized public contracting authorities (especially small municipalities) need a shorter period of time to conclude a contract than do less decentralized authorities (regions) and ministries, in relation to how this comparison was performed. This finding is in line with the decentralization theorem (Oates, 1978) and the concept of "local accountability". At the local level, the public contract is concluded in a shorter time than a public contract at a higher level of government (regions) and ministries. Thus, it can be assumed that the length of the procedure have a higher impact on the conclusion of a public contract at the central level of government than at the decentralized level, where there is a shorter time required to conclude a contract. The question is whether these differences suggest different phases of the efficiency of the administration of public procurement (award procedures) or can be attributed to the specifics of procurement at different levels of decentralization of public administration (excluding facts contained in the aforementioned explanatory variables). The model results show that the quickest contract conclusions, to the contrary, arise from evaluations based only on the tender price or when the victor is a local supplier. In the case of the bid price, the contract procedure is reduced by eight days. This finding is explained by lower administration costs when evaluating the bids, where the evaluation and decision-making are relatively simple compared with the multicriteria evaluation. The quicker times for local contractors can be explained by the idea of"local accountability" where local politicians are under greater scrutiny ("the microscope") from the public. It seems, therefore, that our theoretical assumption that accountability at the local level has a greater potential to influence the behaviour of local actors in public procurement, and that decentralization increases the accountability of politicians to their electorate turns out to be justified. It is in line with our assumption that municipal voters 
"pressure" municipal policy to ensure that purchased products are available as soon as possible. It should be noted that a faster conclusion of the contract may also affect other factors which may cause a "synergistic effect" in influencing the time required to conclude a contract.

For hypothesis H3 we can conclude that it is not surprising that the higher estimated value of procurement affects the time needed to conclude a contract. This factor should be subject to further investigation, as well. The actual impact of the estimated value of public contracts and the length of procedure in public procurement can be explained by the idea of the complexity and the related administrative costs. Public contracts with a higher estimated value have a high probability of having complex public contract evaluations which require a more complex approach and longer times to evaluate the individual bids. This can affect the length of procedure in public procurement. It is apparent that the process above-the-threshold procedure increases the length by an average of 33 days. This finding is not surprising. It is a demanding process to administer and is associated with longer deadlines e.g. for the submission of tenders. Above-the-threshold public contracts may be considered as orders of a higher complexity. The factor of accountability may also play a role when the contracting authority, who is dealing with growth of the estimated value, experiences increased responsibility for public contracting and therefore takes a more time considering all the problems involved with public procurement. The result is (albeit lackluster) an extension of the period which precedes the signing of the contract. The factor of subcontractors leads to an extension of the period by about 3 days. This extension is related to an increase in transaction costs and the complexity of public procurement. The factor of subcontractors is understood as one of several "indicators" of the complexity of public procurement.

Hypothesis 4 also brings interesting results. Among the individual types of procurement procedure, it is worth noting the higher durations involving restricted procedures (51 days) compared to open procedures. This may be due to the high number of phases in these type of procurement procedures and the fact that these procedures are often used for complex and complicated procurements. This finding is therefore in line with the concept of transaction costs and complexity.

The model results show, for H5 which is the case of the bid price, the contract procedure is reduced by eight days. This finding is explained by lower administration costs when evaluating the bids, where the evaluation and decision-making are relatively simple compared with the multi-criteria evaluation.

From the results of the hierarchical regression, it can be seen that both the character of the public contract and the award procedure, which the contracting authority itself can influence, affect the length of the procurement procedure. The effect is thus on both the institutional setting and the behaviour and strategies of the individual contracting authorities.

From the other results, it is interesting that the length of the procurement procedure can be prolonged by more than 93 days when there is a review of public contract with the Competition Office. This finding is also not surprising. Review processes 
have specific deadlines and durations. Therefore, public procurement reviews before the Competition Office leads to a prolongation of the procedure of a public procurement. It was also found that there was less influence of the length of procedure in public procurements by the model when a contract received part of its financing from EU subsidies, a higher number of bids, anticipated use of subcontractors in the implementation of the public contract. These are interesting findings for which there are several explanations. If we interpret the allocation of public contracts as a "decomposition of complexity", then the result may be the opposite effect that we observed in contracting for above-the-threshold procurement, where the time to conclude the contract increases with complexity. If the division into lots means "decomposition of complexity", then this effect may result in a smaller influence of delays in contracts divided into parts. That the financing of public subsidies from the EU extends the length of procedure in public procurement is fairly predictable. This method of financing public contracts is borne by the appropriate administrative processes (compared to unsubsidized government procurement) as "extra paperwork" that prolongs the time to conclude a contract. Subsidies from the EU extend contracts by about a week.

The finding that a higher number of bids has an impact on the time of concluding the contract can be explained by higher administrative expenses. A higher number of offers increases the administrative costs of the procurement process. The effect is not significant. Each offer extends the period for concluding the contract by about two days. This factor would be interesting for further research and further decomposition to determine the stage at which public procurement is influenced by the factor of "the number of bids". It may be, for example, that when evaluating the tenders, the contracting authority carries greater transaction costs to evaluate the bids with each additional offer. A larger number of bids also means more time for evaluation, and thus a longer time for the conclusion of the contract. The effect of having a larger number of bids on the length of procedure may also appear at the contracting stage, where each additional offering increases the likelihood of competing candidates and thus the likelihood of hearings at the Competition Office.

The expected result is that the use of outsourcing in the public procurement process accelerates the whole process, on average by 6 days.

\section{Conclusion}

The study aimed to explore the factors that relate the length of procedure in public procurement from the time of the announcement of the tender to the conclusion of the contract. In the article, we assume that the length of the procurement procedure does not affect the standard contract price, which corroborates the results of the Hypothesis 1 test. Subsequently, we focus in more detail on the factors having an effect on the length of procedure in public procurements. Our results confirm that the type of contracting authority is a statistically significant factor, that is, that municipalities enter their public contracts faster. This is explained by lower complexity and the factor of local accountability. Another statistically significant factor is the assumed value of the contract, due both to longer legal deadlines and to the greater difficulty of preparing large orders. Additionally, an important factor is the openness of the selection procedure where the restricted procedure significantly 
prolongs the awarding process, which may be due in particular to the higher likelihood of objections from the tenderers of the public contract. The length of procedure in public procurement is also affected by the evaluation of the bids according to the lowest price as this method accelerates the whole procedure.

The longer public procurement process has a negative impact on overall efficiency, as we have demonstrated in the assay test that the length of the procurement process does not reduce the resulting price. It is therefore a question of whether the current legislation brings the desired results. Inspiration for improvement can be found, for example, in the United Kingdom which has Strategic Public Procurement Planning, which means better planning of the entire procurement process, including defining public procurement objectives (Murray, 2007). Another inspiring institute is the so-called lean procurement, i.e. the creation of partnership relations between the contracting authority and the supplier, which speeds up the entire procurement process and limits transaction costs (Loader, 2016). In order for these approaches to be applicable in the Czech environment, it is necessary to fulfil the assumption of "maturity" of Czech institutions and their orientation towards achieving goals in the spirit of $3 \mathrm{E}$.

This research opens up other questions that can confirm or refute our thesis as to whether we can associate the length of the public procurement process with terms such as diligence and quality. Additionally, as to whether the length of the process influences the conclusion of the amendments to contracts, the final duration of the project implementation and, ultimately, the quality of the project itself. 


\section{Appendix}

\section{Test results of Hypothesis 1}

The length of the tender process has no statistically significant effect on the standard price

Model: OLS, using observations $1-9,423(\mathrm{n}=8,787)$

Missing or incomplete observations dropped: 636

Dependent variable: norm_price

\begin{tabular}{|l|c|c|c|c|}
\hline & Coefficient & Std. Error & t-ratio & $p$-value \\
\hline constant & 0.872582 & 0.008992 & 97.0370 & $<0.0001^{* * *}$ \\
\hline Procedure_length & 0.000032 & 0.000025 & 1.2557 & 0.2093 \\
\hline In parts & -0.022767 & 0.005632 & -4.0422 & $<0.0001^{* * *}$ \\
\hline Evaluated by price & -0.021866 & 0.004550 & -4.8053 & $<0.0001^{* * *}$ \\
\hline EU subsidies & -0.007816 & 0.003959 & -1.9742 & $0.0484^{* *}$ \\
\hline Number of bids & -0.015286 & 0.000401 & -38.0834 & $<0.0001^{* * *}$ \\
\hline Region & 0.054635 & 0.008696 & 6.2824 & $<0.0001^{* * *}$ \\
\hline Municipality <5,000 inhab. & 0.051691 & 0.008386 & 6.1640 & $<0.0001^{* * *}$ \\
\hline Municipality > 5,000 & 0.030424 & 0.007461 & 4.0779 & $<0.0001^{* * *}$ \\
\hline Subsidized organization & 0.068590 & 0.008005 & 8.5679 & $<0.0001^{* * *}$ \\
\hline Other public institutions & 0.073153 & 0.010630 & 6.8816 & $<0.0001^{* * *}$ \\
\hline State enterprise & -0.056898 & 0.010526 & -5.4055 & $<0.0001^{* * *}$ \\
\hline NGO & 0.092469 & 0.014750 & 6.2693 & $<0.0001^{* * *}$ \\
\hline Private business & 0.062379 & 0.009983 & 6.2488 & $<0.0001^{* * *}$ \\
\hline Restricted procedure & 0.112224 & 0.005865 & 19.1339 & $<0.0001^{* * *}$ \\
\hline
\end{tabular}

\begin{tabular}{|l|r|l|c|}
\hline Mean dependent var & 0.79239 & S.D.dependent var & 0.20374 \\
\hline Sum squared resid & 269.93450 & S.E. of regression & 0.17542 \\
\hline R-squared & 0.25987 & Adjusted R-squared & 0.25869 \\
\hline $\mathbf{F ( 1 4 , 8 7 7 2 )}$ & 220.00000 & P-value(F) & 0.00000 \\
\hline Log-likelihood & $2,833.68500$ & Akaike criterion & $-5,637.37000$ \\
\hline Schwarz criterion & $-5,531.15500$ & Hannan-Quinn & $-5,601.18500$ \\
\hline
\end{tabular}

Source: Authors 


\section{References}

Ahsan, K., Rahman, S. (2017). Green Public Procurement Implementation Challenges in Australian Public Healthcare Sector. Journal of Cleaner Production, 152, 181-197, https://doi.org/10.1016/j.jclepro.2017.03.055

Baldi, S., Bottasso, A., Conti, M., Piccardo, Ch. (2016). To Bid or Not to Bid: That Is the Question: Public Procurement, Project Complexity and Corruption. European Journal of Political Economy, 43, 89-106, https://doi.org/10.1016/j.ejpoleco.2016.04.002

Borowiec, A. (2017). The Impact of Public Procurement System on the Development of Competition in the Economy in the Light of Empirical Research. Oeconomia Copernicana, 8(1), 37-50, https://doi.org/10.24136/oc.v8i1.3

Brezovnik, B., Oplotnik, Ž. J., Vojinovič, B. (2015). (De)centralization of Public Procurement at the Local Level in the EU. Transylvanian Review of Administrative Sciences, 2015(46E), 37-52, https://doi.org/10.1111/j.1468-0297.2006.01049.x

Carson, S. J., Madhok, A., Wu, T. (2006). Uncertainty, Opportunism, and Governance: the Effects of Volatility and Ambiguity on Formal and Relational Contracting. The Academy Management Journal, 49(5), 1058-1077, https://doi.org/10.5465/AMJ.2006.22798187

Coviello, D., Mariniello, M. (2014). Publicity Requirements in Public Procurement: Evidence from a Regression Discontinuity Design. Journal of Public Economics, 109, 76-100, https://doi. org/10.1016/j.jpubeco.2013.10.008

Dametri, R. P. (2012). Centralization vs Decentralization of Purchasing in the Public Sector: The Role of e- Procurement in the Italian Case. In Khachidze, V. (ed.) iCETS 2012: 457-470

De Schepper, S., Haezendonck, E., Dooms, M. (2015). Understanding Pre-Contractual Transaction Costs for Public-Private Partnership Infrastructure Projects. International Journal of Project Management, 33(4), 932-946, http://doi.org/10.1016/j. ijproman.2014.10.015

Decarolis, F., Palumbo, G. (2015). Renegotiation of Public Contracts: An Empirical Analysis. Economics Letters, 132, 77-81, https://doi.org/10.1016/j.econlet.2015.04.025

Dosi, C., Moretto, M. (2015). Procurement with Unenforceable Contract Time and the Law of Liquidated Damages. Journal of Law Economics \& Organization, 31(1), 160-186, https://doi.org/10.1093/jleo/ewt020

Erdis, E. (2013). The Effect of Current Public Procurement Law on Duration and Cost of Construction Projects in Turkey. Journal of Civil Engineering and Management, 19(1), 121-135, https://doi.org/10.3846/13923730.2012.746238

Fazekas, M., Toth, I. J., King, P. L. (2016). An Objective Corruption Risk Index Using Public Procurement Data. European Journal on Criminal Policy and Research, 22(3), 369-397, http://doi.org/10.1007/s10610-016-9308-z

Guccio, C., Pignataro, G., Rizzo, I., (2014). Do Local Governments Do It Better? Analysis of Time Performance in the Execution of Public Works. European Journal of Political Economy, 34, 237-252, https://doi.org/10.1016/j.ejpoleco.2014.01.010

Lennerfors, T. T. (2007). The Transformation of Transparency - on the Act on Public Procurement and the Right to Appeal in the Context of the War on Corruption. Journal of Business Ethics, 73(4), 381-390, https://doi.org/10.1007/s10551-006-9213-3

Loader, K. (2010). Is Local Authority Procurement 'Lean'? An Exploration to Determine if 'Lean' Can Provide a Useful Explanation of Practice. Journal of Purchasing and Supply Management, 16(1), 41-50, https://doi.org/10.1016/j.pursup.2009.10.001 
Loader, K. (2016). Is Local Authority Procurement Supporting SMEs? An Analysis of Practice in English Local Authorities. Local Government Studies, 42(3), 464-484, http://doi.org/10.10 80/03003930.2016.1157068

Lundberg, S., Bergman, M. (2017). Tendering Design when Price and Quality Is Uncertain. International Journal of Public Sector Management, 30(4), 310-327, http://doi.org/10.1108/ IJPSM-04-2016-0063

Moe, C. R., Newman, M., Sein, K. M. (2017). The Public Procurement of Information Systems: Dialectics in Requirements Specification. European Journal of Information Systems, 26(2), 143-163, http://doi.org/10.1057/s41303-017-0035-4

Murray, G. (2007). Strategic Procurement in UK Local Government: The Role of Elected Members. Journal of Public Procurement, 7(2), 194-212.

Nikou, Ch., Moschuris, S., Filiopoulos, I. (2017). An Integrated Model for Supplier Selection in the Public Procurement Sector of Defence. International Review of Administrative Sciences, 83(1), 78-98, http://doi.org/10.1177/0020852316634446

Ochrana, F., Pavel, J. (2013). Analysis of the Impact of Transparency, Corruption, Openness in Competition and Tender Procedures on Public Procurement in the Czech Republic. Central European Journal of Public Policy, 7(2), 114-135.

OECD (2000). Centralised and Decentralised Public Procurement. Sigma Papers, 2000, No. 29, Paris: OECD Publishing, https://doi.org/10.1787/5kml60w5dxr1-en

OECD (2007). Central Public Procurement Structures and Capacity in Member States of the European Union. Sigma Paper, No. 40, Paris: OECD Publishing, https://doi.org/10.1787/5kml60qdqq0n-en

OECD (2011). Centralized Purchasing Systems in the European Union. Sigma Papers, 2011, no. 47, Paris, OECD Publishing, https://doi.org/10.1787/5kgkgqv703xw-en

OTIDEA (2016). Public Procurement 2010-2015: Expert Report Mapping the Area of Public Procurement in the Czech Republic. Prague. Czech Republic.

Plaček, M., Schmidt, M., Ochrana, F., Půček, M. (2017). Do the Selected Characteristics of Public Tenders Affect the Likehood of Filling Petition with Regulators of Public Tenders? Prague Economics Papers, 26(3), 317-329, https://doi.org/10.18267/j.pep.616

Plaček, M., Ochrana, F., Schmidt, M., Půček, M. (2016). The Evaluation of Role of the Office for Protection and Competition of the Czech Republic in Regulating Public Procurement. NISPAcee Journal of Public Administration and Policy, 9(1), 97-117, http://doi.org/10.1515/ nispa-2016-0005

Rose-Ackerman, S. (1999). Corruption and Government: Causes, Consequences, and Reform. New York, NY: Cambridge University Press. ISBN 9781107441095.

Sanchez Solino, A., Gago de Santos, P. (2016). Influence of the Tendering Mechanism in the Performance of Public-Private Partnerships: A Transaction Cost Approach. Public Performance \& Management Review, 40(1), 97-118, http://doi.org/10.1080/1530957 6.2016.1177558

Schmidt, M., Plaček, M., Ochrana, M., Půček, M. (2016). An Empirical Analysis of PostContractual Behavior in Public Works Contracts: The Czech Case as a Secondary Comparison with the Slovak Republic. Ekonomický časopis, 64(6), 501-518, http://doi. org/10.15240/tul/001/2016-4-007

Soliño, A. S., Gago de Santos, P. (2010). Transaction Costs in Transport Public-Private Partnerships: Comparing Procurement Procedures. Transport Reviews, 30(2010), 389-406, http://doi.org/10.1080/01441640903037941 
Stloukalová, T., Jurčík, R. (2015). Relationship between Estimated Value of Public Contract and its Price. Proceedings of the 12th International Scientific Conference European Financial Systems, Brno, Czech Republic: 544-551.

Tkachenko, A., Yakovlev, A., Kuznetsova, A. (2017). Sweet Deal's: State-Owned Enterprises, Corruption and Repeated Contracts in Public Procurement. Economic Systems, 41(1), 52-67, http://doi.org/10.1016/j.ecosys.2016.12.002

Williamson, O. E. (1985). The Economic Institutions of Capitalism: Firms, Markets, Relational Contracting. New York, NY: Free Press.

Wooldridge, J. (1999). Econometric Analysis of Cross Section and Panel Data. MIT Press. 